\title{
증 례
}

\section{침대돌기위 내경 둥맥류로 인한 단안 고도의 상방 시야결손}

연세대학교 의과대학 강남세브란스병원 신경과

김선정 송태진 서경임 최영철 김원주

\section{Monocular Superior Altitudinal Field defect due to Supraclinoid Internal Carotid Artery Aneurysm}

\begin{abstract}
Seon-Jeong Kim, MD, Tae-Jin Song, MD, Gyungim Suh, MD, Young-Chul Choi, MD, Won-Joo Kim, MD

Departments of Neurology, Gangnam Severance Hospital, Yonsei University College of Medicine, Seoul, Korea

An altitudinal visual-field defect is confined to the upper or lower half of the visual field but crosses the vertical median. Slight arteritis usually causes ischemic optic neuropathy, with a compressive lesion causing optic neuropathy in rare cases. We report a 46-year-old woman with a monocular superior altitudinal visual defect due to an aneurysm in the supraclinoid portion of the internal carotid artery. It appeared that the ipsilateral cerebral aneurysm compressed the optic nerve and secondarily caused posterior ischemic optic neuropathy.

J Korean Neurol Assoc 27(1):58-60, 2009
\end{abstract}

Key Words: Altitudinal visual-field defect, Aneurysm, Optic nerve

상방 수평시야결손(superior altitudinal visual field defect) 은 망막, 시각신경, 뇌 피질에 병변이 있을 경우에 발생할 수 있 다. ${ }^{1}$ 시각신경에서 발생하는 흔한 기전으로는 시각신경에 분포 하는 작은 혈관들이 폐색되며 생기는 시각신경 허혈증상이다. ${ }^{2}$ 이때에 침범되는 혈관의 위치에 따라 시각신경의 전방부위(시 각신경 두위부)와 후방부위로 나뉘게 된다. 이러한 시각신경 허혈을 일으키는 원인으로 주로 혈관염이 알려져 있다. 그러나 혈관염에 의하여 발생하는 시야결손뿐만 아니라 시각신경구멍 의 골절, 동맥류나 종양 등에 의한 압박에 의하여 수평시야결손 이 발생하는 경우도 드물게 보고되고 있다. ${ }^{3}$

저자들은 내경동맥 침대돌기위(supraclinoid) 분절에 생긴 동맥류에 의한 단안의 상방 수평시야결손이 발생한 환자를 경 험하였기에 보고한다.

Received August 20, 2008

Revised December 17, 2008

Accepted December 24, 2008

* Won-Joo Kim, MD

Departments of Neurology, Gangnam Severence Hospital,

612 Eonjuro, Gangnam-gu, Seoul, 135-720, Korea

Tel: +82-2-2019-3324 Fax: +82-2-3462-5904

E-mail: kzoo@yuhs.ac

\section{중 례}

46세 여자가 일주일 전부터 갑자기 왼쪽 눈이 잘 안 보이는 증상으로 내원하였다. 신경학적 검사상 동공 크기 및 대광반사는 직접반사와 간접반사 모두 보전되어 있었고, 대면 검사상 왼쪽 눈에서 위 부분의 시야장애가 의심되었고, 안과 시야 검사에서 왼쪽 상방 수평시야결손이 확인되었다(Fig. 1-A). 안저 검사상 유두부종이나 위축, optociliary shunt는 보이지 않았다. 시각 유발전위 검사상 왼쪽에서 오른쪽에 비하여 $\mathrm{p} 100$ 의 잠복기가 지연되어 있었다(좌안 $155 \mathrm{~ms}$, 우안 $99.1 \mathrm{~ms}$ ). 안와 및 뇌 자기 공명 촬영에서 뇌 실질 병변은 없었으며, 조영증강은 명확하지 않으나 시각신경 구멍을 누르는 구조물을 발견하였다(Fig. 2-A). 안구 전산화단층촬영 결과 왼쪽 눈동맥 부위에 약 $1 \mathrm{~cm}$ 되는 동 맥류가 관찰되었다(Fig. 2-B). 뇌혈관조영술에서는 왼쪽 내경 동맥 상방 앞쪽 방향으로 침대돌기위 분절에 $10 \times 8.5 \times 8.9 \mathrm{~mm}$ 크기의 동맥류가 있었고, 동맥염을 시사하는 구슬모양의 형상 (beaded appearance)이나 미세동맥류 등의 이상은 없었다 (Fig. 3-A). 치료를 위하여 Guglielmi Detachable Coil (GDC) 색전술을 하였다(Fig. 3-B). 색전술 이후 1 개월 지나 외래 경과 

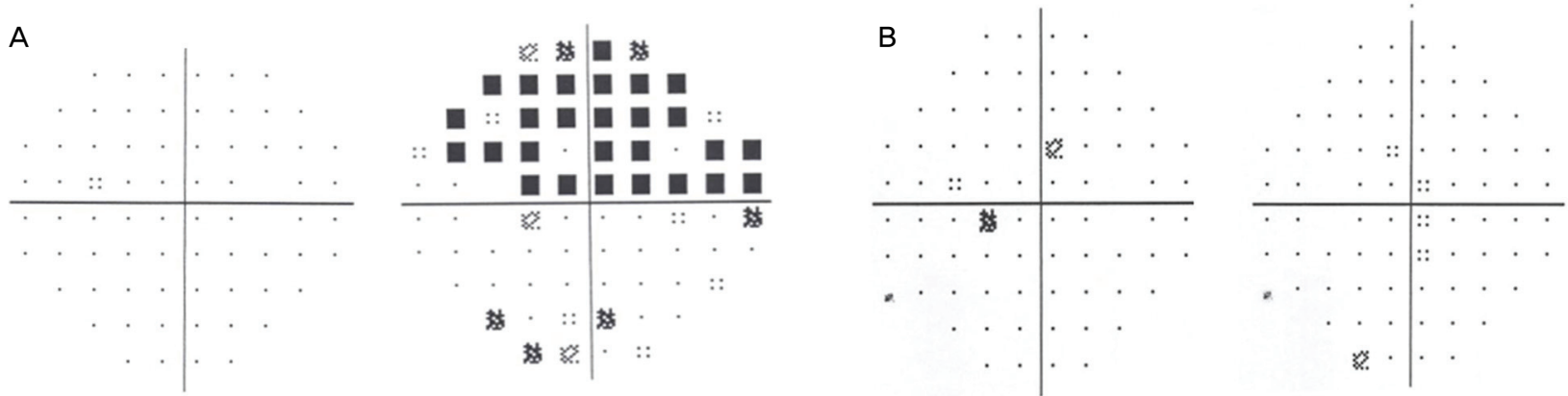

Figure 1. The perimetries demonstrate the left monocular superior altitudinal field defect (A) and normalization of the field defect 9 months later (B).
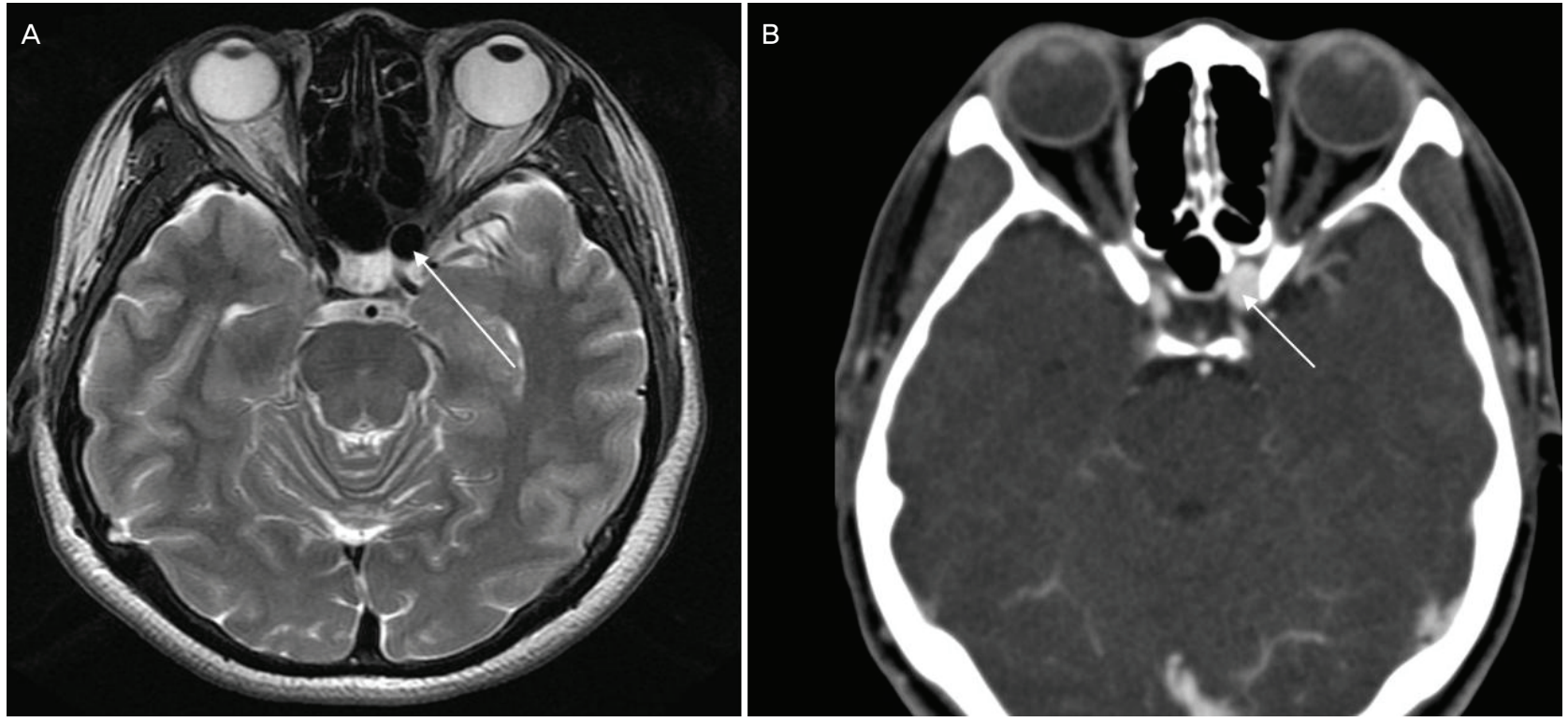

Figure 2. MRI (A) and CT (B) disclose a structure that compress the optic foramen.

관찰 시 환자가 왼쪽 눈의 시야가 넓어졌다고 주관적으로 표현 할 정도로 시야장애는 호전되었다. 색전술 9 개월 뒤 시야와 안저 검사는 정상이었다(Fig. 1-B).

\section{고 찰}

수평시야결손은 상방 혹은 하방 반구에 국한되고 수직 경계 선을 넘어서는 시야결손을 의미한다. ${ }^{2}$ 수평시야결손의 원인은 크게 세 가지로 나눌 수 있는데 첫째는 망막동맥, 정맥가지의 폐색, 망막 결손 등 망막성 병변, 둘째는 허혈성 시각신경병증 (동맥성 혹은 비동맥성), 유두부종, 시각신경 유두 무형성 등의 시각신경 병변이고, 셋째로 상하방 새발톱고랑(calcarine sulcus), 측두엽, 두정엽에 영향을 주는 종양 등 뇌 피질에 발생한 병변이 있다. ${ }^{4}$ 이들 중에서 뇌 피질 병변에 의한 시야결손은 반드

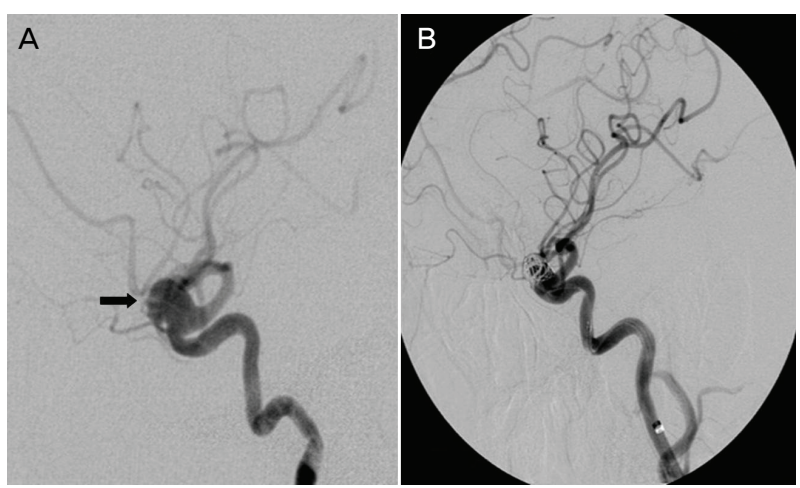

Figure 3. Cerebral angiography (A) demonstrates the preprocedure supraclinoid internal carotid aneurysm and the cerebral catheter embolization (B) represent the post-procedure state.

시 양안을 침범하기 때문에 본 증례의 원인일 가능성은 낮았다. 양안 수평시야결손과 달리 단안 수평시야결손은 주로 뒤 섬 
모체 혈관(posterior ciliary vessel)들의 폐색으로 인한 허혈성 신경병증으로 발생하며 ${ }^{2}$ 두 개의 상하 가지들로 이루어져 있는 망막동맥의 한 가지가 색전으로 막히는 경우에 단안 수평시야 결손이 생길 수 있는데, ${ }^{5}$ 허혈이 발생한 부위에 따라 전방부위 와 후방부위로 나뉘게 된다. 전방부위에 허혈증이 오면 유두부 종이 동반되나, 후방부위에 허혈이 오면 안저는 정상을 보여 쉽 게 감별이 된다. ${ }^{6}$ 대부분의 경우에서 1 달 이상 시간이 경과되면 망막에 색소는 침착되지 않으며 안저가 창백하게 변하지만, 약 $15 \%$ 에서는 초기 허혈이 심하지 않아 시력도 유지되고 망막의 변화도 생기지 않는다. ${ }^{7}$ 본 증례에서도 안저 검사에서 유두부종 이 관찰되지 않고 시력이 추적 검사에서 호전된 결과로 보아 허 혈이 심하지 않아 망막의 변화가 없었던 것으로 추정된다. 허혈 증은 주로 작은 혈관에 염증을 일으키는 질병들에 의해 발생 하는 경우가 많다. 전방에서 고도의 신경결손은 앞쪽의 짧은 뒤 섬모체 동맥(short posterior cilliary arteries)의 시각신경 주변 가지 영역(paraoptic branches territory) 내의 감소된 관 류압이 시각신경의 관류압을 저하시키고 이것이 시각신경유두 관류저하를 일으켜 수평방향으로 시야결손을 유발하는 것으로 여겨지고 있다. 그러나 후방 허혈성 시각신경병증에서는 측부 혈관이 발달되어 있어 혈류역학 기전에 의하여 발생되는 일이 흔하지 않다. ${ }^{7}$

본 증례 환자의 경우와 같은 동맥류나 안와골절, 종양에 의 하여 수평시야장애가 생기는 경우는 매우 드물다. 동맥류에 의 하여 시야장애가 발생하는 기전은 크게 두 가지로 설명되고 있 다. 첫째는 시각신경이 지속적인 압박을 받기 때문에 2 차적으로 탈수초가 되며 증상이 발현되는 경우이다. Walsh와 Hoyt가 제 시한 바에 따르면 체판(lamina cribrosa)에서 시각신경교차에 이르는 시각신경에서 네 개의 사분역으로부터 나오는 섬유들은 망막에 있는 위치와 일치하고 당겨지는 부위에 따라서 여러 모 양의 시야장애가 생길 수 있으며 하나의 시각신경의 아랫부분 이 지속적으로 당겨지거나 압박되면 신경다발의 탈수초 현상이 생기며 단안의 상방 시야결손이 나타날 수 있다고 한다. ${ }^{8}$

둘째는 동맥류가 시각신경으로 분포하는 혈관을 폐쇄시켜 발생하는 허혈에 의한 원인이다. ${ }^{3}$ 내경동맥 침대돌기위분절의 내경동맥류가 후방 허혈성 시각신경병증을 일으킨다고 추정하 는데 시각신경 후방부는 중심망막동맥(central retinal artery) 진입(entry) 여부에 따라서 앞분절과 뒤분절로 나눌 수 있다. 앞분절은 유두모양주위맥락막(peripapillary choroids), ZinnHaller 동맥고리, 중심망막동맥(central retinal artery), 눈동맥 (ophthalmic artery) 그리고 다른 눈확동맥들(orbital arteries) 로부터 시작되는 다수의 연질막 혈관가지들 (pial branches)에 서 혈액을 공급받는다. 뒤분절은 눈동맥(ophthalmic artery)과 눈확동맥들(orbital arteries)에서 직접 시작되는 다수의 곁동맥 (collateral arteries)들로 구성되는 연질막 혈관얼기(pial vascular plexus)에 의하여 생성되는 말초의 구심 혈관계에 의하여 혈액을 공급받기 때문에 동맥류가 이러한 혈관을 압박하여 허 혈이 발생된다는 설명이다. ${ }^{7}$

동맥류에 의한 탈수초성 시야장애 증상은 대부분이 수개월에 서 수주에 걸쳐 진행되는 아급성의 양상으로 나타나지만 허혈 에 의한 장애는 급성으로 나타나기 때문에, 본 증례에서 시야 장애 발생 기전은 동맥류에 의한 2 차성 허혈로 추정하였다. 본 증례의 경우에서 동맥류가 시각신경 하부를 누르면서 눈동맥 (ophthalmic artery) 및 눈확동맥(orbital arteries) 및 연질막 혈관얼기(pial vascular plexus)에 허혈이 생기며 시야장애가 왔다고 판단하였다.

동맥류에 coil 색전술을 시행하게 되면 혈류역학적으로 동맥 류 안의 혈류가 감소되고 혈관 벽에 미치는 압력이 감소하여 동 맥류 자체의 압력 효과가 감소된다. ${ }^{9}$ 이 기전에 의하여 환자의 증상이 색전술 이후 호전되었다고 생각된다.

저자들은 단안 상방 수평시야결손으로 내원한 환자에서 원인 질환으로 내경동맥의 침대돌기위 분절에 동맥류를 발견하여 보고한다.

\section{REFERENCES}

1. Lakhanpal A, Selhorst JB. Bilateral altitudinal visual fields. Ann Ophthalmol 1990;22:112-117.

2. Ropper AH, Brown RH. Adams and Victor's principles of neurology. 8th ed. New York: Mc Graw-Hill, 2005;218-219.

3. Cestari DM, Rizzo JF 3rd. The neuroophthalmic manifestations and treatment options of unruptured intracranial aneurysm. Int Ophthalmol Clin 2004;44:169-187.

4. Shingleton BJ, O'Donoghue MW. Blurred vision. N Engl J Med 2003;343:556-562.

5. Trego ME, Pagani JM. Three presentations of monocular vision loss. Optometry 2006;77:82-87.

6. Paul B, McElvanney AM, Agarwal S, Bruckner FE, Ayliffe W. Two rare causes of posterior ischemic optic neuropathy: eosinophilic fasciitis and Wegener's granulomatosis. Br J Opthamol 2002;86:1066-1068.

7. Hayreh SS. Posterior ischemic optic neuropathy: clinical features, pathogenesis, and management. Eye 2004;18:1180-1206.

8. Vanroose E, Marchau M, Dehaene I, Lammens M. Altitudinal hemianopia; a clinical and anatomical entity or a more coincidence? Case report and review of literature. Acta Neurol Belq 1990;90:254-264.

9. Kim M, Taulbee DB, Tremmel M, Meng H. Comparison of two stents in modifying cerebral aneurysm hemodynamics. Ann Biomed Eng 2008;36:726-741. 